\title{
PET of Tumor CXCR4 Expression with $4-{ }^{18}$ F-T140
}

\author{
Orit Jacobson $^{1}$, Ido D. Weiss ${ }^{2}$, Dale O. Kiesewetter ${ }^{1}$, Joshua M. Farber ${ }^{2}$, and Xiaoyuan Chen $^{1}$ \\ ${ }^{1}$ Laboratory of Molecular Imaging and Nanomedicine, National Institute of Biomedical Imaging and Bioengineering, National \\ Institutes of Health, Bethesda, Maryland; and ${ }^{2}$ Laboratory of Molecular Immunology, National Institute of Allergy and Infectious \\ Diseases, National Institutes of Health, Bethesda, Maryland
}

Expression of the chemokine receptor CXCR4 by cancers has been shown to correlate with tumor aggressiveness and poor prognosis and may also contribute to metastatic seeding of organs that express its ligand SDF-1. However, fully optimized PET agents for determining CXCR4 expression by tumor cells in vivo are not yet available. This study aims to develop a stable, ${ }^{18} \mathrm{~F}$-labeled peptide that enables in vivo quantification of CXCR4 in cancer. Methods: 4-F-benzoyl-TN14003 (4-F-T140), a short peptide antagonist of CXCR4 with 1-(4,4-dimethyl-2,6-dioxocyclohexylidene)ethyl protecting groups on the $\epsilon$-amino groups of the lysine residues, was labeled with ${ }^{18} \mathrm{~F}$-fluoride via $\mathrm{N}$-succinimidyl-4-18F-fluorobenzoate conjugation, followed by deprotection to give $4-{ }^{18} \mathrm{~F}-\mathrm{T} 140$ that was exclusively labeled on the $\alpha$-amine at the $\mathrm{N}$ terminus. Cell binding, migration, biodistribution, and small-animal PET studies of $4-{ }^{18} \mathrm{~F}-\mathrm{T} 140$ were performed. Results: 4-F-T140 was radiolabeled by coupling with $\mathrm{N}$-succinimidyl-4-18 F-fluorobenzoate, with an overall decaycorrected radiochemical yield of $15 \% \pm 5 \%$ calculated from the start of synthesis. The mean measured specific activity $( \pm \mathrm{SD})$ was $7 \pm 2 \mathrm{GBq} / \mu \mathrm{mol}(0.19 \pm 0.05 \mathrm{Ci} / \mu \mathrm{mol})$, and radiochemical purity was greater than $99 \% .4-18 \mathrm{~F}-\mathrm{T} 140$ was found to bind specifically to red blood cells in vitro and in vivo. The binding of $4-{ }^{18} \mathrm{~F}-\mathrm{T} 140$ to red blood cells was blocked with a small amount of cold 4-F-T140, which led to higher uptake of $4-{ }^{18} \mathrm{~F}-$ T140 by Chinese hamster ovarian (CHO)-CXCR4 tumors. Biodistribution experiments at $3 \mathrm{~h}$ after injection with the addition of $10 \mu \mathrm{g}$ of cold $4-\mathrm{F}-\mathrm{T} 140$ showed a $3.03 \pm 0.31$ percentage injected dose per gram uptake in CHO-CXCR4 tumors, with a tumor-to-blood ratio of $27.1 \pm 8.7$ and a tumor-to-muscle ratio of $21.6 \pm 7.1$. PET studies demonstrated clear visualization of CXCR4-transfected, but not CXCR4-negative, CHO tumors. Conclusion: $4-{ }^{18} \mathrm{~F}-\mathrm{T} 140$ can be used as a PET tracer to image tumor expression of CXCR4, with a high tumor-to-background ratio. The knowledge of whether tumors express or do not express CXCR4 might be beneficial in determining appropriate treatment and monitoring.

Key Words: T140 peptide; CXCR4; PET; ${ }^{18}$ F-fluoride

J Nucl Med 2010; 51:1796-1804

DOI: 10.2967/jnumed.110.079418

\footnotetext{
Received May 24, 2010; revision accepted Jul. 15, 2010.

For correspondence or reprints contact: Xiaoyuan Chen, National Institute of Biomedical Imaging and Bioengineering (NIBIB), National Institutes of Health (NIH), Bldg. 31, Room 1C22, 31 Center Dr. MSC 2281, Bethesda, MD 20892.

E-mail: shawn.chen@nih.gov

COPYRIGHT @ 2010 by the Society of Nuclear Medicine, Inc.
}

C hemokine receptors are G-protein-coupled receptors containing 7 transmembrane domains that direct cell movement toward higher concentrations of chemokines. CXCR4 is unique among chemokine receptors in having fundamental roles beyond leukocyte recruitment in the hematopoietic, cardiovascular, reproductive, and nervous systems during embryonic development (1). CXCR4 also has a role in disease and serves as a coreceptor for HIV on CD4 T cells (2,3). SDF-1/CXCL12, the sole known native ligand for CXCR4, is expressed in the bone marrow and at other sites and directs CXCR4-expressing stem cells to home to the bone marrow.

CXCR4 was found to be expressed by many different types of human cancers, including breast, prostate, lung, lymphoma, multiple myeloma, melanoma, ovarian, pancreatic, neuroblastoma, esophageal, colorectal, osteosarcoma, and renal carcinoma (4-9). Recent studies have correlated high levels of CXCR4 expression in cancers with tumor aggressiveness, poor prognosis, and resistance to chemotherapy (10-14). Expression of CXCR4 may also contribute to metastatic seeding of organs that express SDF-1 and support the survival of these cells $(15,16)$. Overall, the data on CXCR4 in cancer suggest that this receptor can increase tumor survival, growth, and metastasis, making it a potentially attractive target for quantitative imaging and therapy. The ability to evaluate CXCR4 expression by tumors noninvasively using PET could be useful in diagnosing cancer, predicting tumor behavior, and predicting and evaluating responses to current and experimental therapies (including therapies targeting CXCR4).

We and others have previously reported a small-molecule CXCR4-targeted radioligand, ${ }^{64} \mathrm{Cu}-\mathrm{AMD} 3100$, as an imaging agent for CXCR4 quantification in vivo (17-18). In the current study, we developed a new ${ }^{18} \mathrm{~F}$-labeled peptide imaging agent, 4- ${ }^{18}$ F-benzoyl-TN14003 (4- ${ }^{18}$ F-T140) (Fig. 1), based on the highly selective CXCR4 antagonist 4-Fbenzoyl-TN14003. Here we report on the evaluation of this new tracer for its potential to visualize CXCR4 levels in vivo in xenografts using PET.

\section{MATERIALS AND METHODS \\ General}

Kryptofix 2.2.2 was purchased from EMD Chemicals. All other solvents and chemicals were purchased from Sigma-Aldrich Co. 


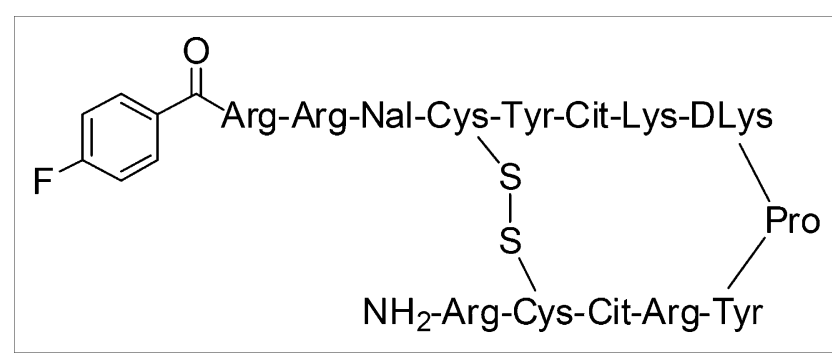

FIGURE 1. Schematic structure of 4-F-T140.

Pentamethylbenzyl 4-(N,N,N-trimethylammonium)benzoate trifluoromethanesulfonate was prepared according to a known procedure (19). ${ }^{18}$ F-fluoride was obtained from the National Institutes of Health (NIH) Clinical Center cyclotron facility from irradiation of an ${ }^{18} \mathrm{O}$-water target by the ${ }^{18} \mathrm{O}(p, n)^{18} \mathrm{~F}$ nuclear reaction. $\mathrm{C}_{18}$ cartridges (Waters Corp.) were each activated with $5 \mathrm{~mL}$ of EtOH and $10 \mathrm{~mL}$ of water. Silica cartridges (Sep Pak Light; Waters Corp.) were not activated before use. Radio-thin-layer chromatography (TLC) was performed on a scanner (AR-2000; Bioscan), using silica gel plates (K18F, $6 \mathrm{~nm}$ [60 ̊], $200 \mathrm{~mm}$; Whatman) and $5 \%$ methanol:0.5\% acetic acid in dichloromethane as a developing solvent. All the peptides were purchased from Pro-Immune, which provided analytic high-performance liquid chromatography (HPLC) of the 4-F-T140 (retention time, $11.4 \mathrm{~min}$ ) and T140protected peptide (retention time, $13.4 \mathrm{~min}$ ) and mass spectrometry (4-F-T140: $\mathrm{m} / \mathrm{z} 2,163$ for $[\mathrm{MH}]^{+}$and T140-protected peptide: $\mathrm{m} / \mathrm{z} 2,367$ for $\left.[\mathrm{MH}]^{+}\right)$.

\section{Synthesis of $\boldsymbol{N}$-succinimidyl $4-{ }^{18} \mathrm{~F}$-fluorobenzoate (18F-SFB)}

Radiosyntheses were performed on a modular system (Eckert \& Ziegler Eurotope $\mathrm{GmbH}$ ) set up with 2 reaction vials. ${ }^{18} \mathrm{~F}$-fluoride solution $(300-400 \mu \mathrm{L})$ was transferred to the first reaction vial, without trapping on an anion exchange cartridge, followed by the addition of $\mathrm{K}_{2} \mathrm{CO}_{3}(8.63 \mathrm{mg} / \mathrm{mL}, 5 \mu \mathrm{mol})$ and Kryptofix 2.2 .2 (4.5 $\mathrm{mg}, 12 \mu \mathrm{mol})$ in $10 \%$ water:acetonitrile solution. Then, water and acetonitrile were azeotropically evaporated by heating the reactor to $120^{\circ} \mathrm{C}$ under a stream of argon followed by a vacuum. Further azeotropic drying was accomplished by the addition of $0.5 \mathrm{~mL}$ of acetonitrile. The dried $\mathrm{K}^{18} \mathrm{~F} \bullet$ Kryptofix 2.2 .2 complex was then dissolved in $400 \mu \mathrm{L}$ of acetonitrile containing $5 \mathrm{mg}(14.7 \mu \mathrm{mol})$ of pentamethylbenzyl 4-(N,N,N-trimethylammonium)benzoate trifluoromethanesulfonate. The reactor was sealed and heated to $105^{\circ} \mathrm{C}$ for $10 \mathrm{~min}$, to yield $4-{ }^{18} \mathrm{~F}$-fluorobenzoic acid pentamethylphenylmethyl ester. Then, the reactor was cooled to $10^{\circ} \mathrm{C}$ and 0.8 $\mathrm{mL}$ of diethyl ether was added. The crude $4-{ }^{18} \mathrm{~F}$-fluorobenzoic acid pentamethylphenylmethyl ester solution was then transferred through the silica cartridge to the second reaction vial. The first reaction vial and silica cartridge were washed with an additional 0.8 -mL portion of diethyl ether. The diethyl ether was evaporated for $5 \mathrm{~min}$ at $35^{\circ} \mathrm{C}$ under a stream of argon. Then the reaction vial was cooled to $25^{\circ} \mathrm{C}$, and $0.15 \mathrm{~mL}$ of $99.9 \%$ trifluoroacetic acid (TFA) was added. The pentamethylbenzyl deprotection proceeded for $2 \mathrm{~min}$ to yield $4-{ }^{18} \mathrm{~F}$-fluoro-benzoic acid $\left({ }^{18} \mathrm{~F}-\mathrm{FBA}\right)$. Thereafter, the reaction vial was cooled to $4^{\circ} \mathrm{C}$, and TFA was evaporated under a stream of argon, followed by the addition of $3 \mathrm{mg}$ of 4-(dimethylamino)pyridine and $5.2 \mathrm{mg}$ of $N, N^{\prime}$-disuccinimidyl carbonate. The reactor was sealed and heated to $100^{\circ} \mathrm{C}$ for
$5 \mathrm{~min}$. The reaction vial was then cooled to $30^{\circ} \mathrm{C}$, and the crude ${ }^{18} \mathrm{~F}-\mathrm{SFB}$ was diluted with $20 \mathrm{~mL}$ of water and passed through an activated $\mathrm{C}_{18}$ cartridge. The cartridge was washed with $10 \mathrm{~mL}$ of water and $1.8 \mathrm{~mL}$ of petroleum ether. Finally, the ${ }^{18} \mathrm{~F}-\mathrm{SFB}$ was eluted from the cartridge with $1 \mathrm{~mL}$ of dichloromethane. The solvent was removed by a stream of argon at $25^{\circ} \mathrm{C}$. ${ }^{18} \mathrm{~F}-\mathrm{SFB}$ quality control analysis was performed on a Vydac C4 (214TP5415, $5 \mu \mathrm{m}$, $4.6 \times 150 \mathrm{~mm}$ ) column, using a gradient system starting from $100 \%$ of solvent A ( $0.1 \%$ TFA in water) and $0 \%$ of solvent B $(0.1 \%$ TFA in acetonitrile) for $5 \mathrm{~min}$ and increasing to $50 \%$ solvent $\mathrm{A}$ and $50 \%$ solvent $\mathrm{B}$ at $30 \mathrm{~min}$, with a flow of $1.5 \mathrm{~mL} / \mathrm{min}$ and a retention time of 10.9 min. ${ }^{18} \mathrm{~F}-\mathrm{SFB}$ was also analyzed by radio-TLC with an $\mathrm{R}_{\mathrm{f}}$ of 0.9 .

\section{Synthesis of $4-{ }^{18} \mathrm{~F}-\mathrm{T} 140$}

${ }^{18} \mathrm{~F}-\mathrm{SFB}$ was redissolved in $100 \mu \mathrm{L}$ of dimethylformamide. The T140 peptide precursor, which contained protecting groups on both lysine residues ( $1 \mathrm{mg}$ in $50 \mu \mathrm{L}$ of dimethylformamide), was added, followed by $550 \mu \mathrm{L}$ of $\mathrm{Na}_{2} \mathrm{HPO}_{4}$ buffer $(\mathrm{pH} 8.3$ ), and incubated at $25^{\circ} \mathrm{C}$ for $40 \mathrm{~min}$. Formation of $4-{ }^{18} \mathrm{~F}-\mathrm{T} 140$ was monitored by radio-TLC $\left(\mathrm{R}_{\mathrm{f}}\right.$ of ${ }^{18} \mathrm{~F}-\mathrm{SFB}, 0.9 ; \mathrm{R}_{\mathrm{f}}$ of $4-{ }^{18} \mathrm{~F}-\mathrm{T} 140$, $0.05)$. Hydrolysis of the lysine protecting groups, $N-[1-(4,4-$ dimethyl-2,6-dioxocyclohex-1-ylidene)ethyl] (Dde), was done by adding $2 \%(\mathrm{~V} / \mathrm{V})$ hydrazine. The mixture was then incubated for $10 \mathrm{~min}$ at $25^{\circ} \mathrm{C}$.

${ }^{4-}{ }^{18} \mathrm{~F}-\mathrm{T} 140$ was purified on a reversed-phase HPLC system using a Vydac C4 (214TP510, $5 \mu \mathrm{m}, 10 \times 250 \mathrm{~mm})$ column. The flow was set at $4 \mathrm{~mL} / \mathrm{min}$ using a gradient system starting from $100 \%$ of solvent $\mathrm{A}(0.1 \%$ TFA in water $)$ and $0 \%$ of solvent $\mathrm{B}$ (0.1\% TFA in acetonitrile) and increasing to $70 \%$ solvent $\mathrm{A}$ and $30 \%$ solvent $\mathrm{B}$ at $30 \mathrm{~min}$. The retention time of $4-{ }^{18} \mathrm{~F}-\mathrm{T} 140$ on this system was $23.6 \mathrm{~min}$. The HPLC solution of $4-{ }^{18} \mathrm{~F}-\mathrm{T} 140$ was diluted with $10 \mathrm{~mL}$ of water and loaded on an activated C-18 cartridge. The cartridge was washed with $10 \mathrm{~mL}$ of water, and 4- ${ }^{18} \mathrm{~F}-\mathrm{T} 140$ was eluted with $10 \mathrm{mM} \mathrm{HCl}$ in ethanol. The ethanol was completely evaporated under a stream of argon, and $4-{ }^{18} \mathrm{~F}$ T140 was formulated in phosphate-buffered saline (PBS) for further use in vitro and in vivo.

The concentration of radiolabeled ${ }^{4-}{ }^{18} \mathrm{~F}-\mathrm{T} 140$ was determined by measuring ultraviolet absorbance at $280 \mathrm{~nm}$ on a NanoDrop spectrophotometer (ND-1100; Grace Scientific) and compared with a standard curve. Quality control analysis was performed on a Vydac C4 (214TP5415, $5 \mu \mathrm{m}, 4.6 \times 150$ $\mathrm{mm}$ ) column, using the same gradient system, and a flow of 1.5 $\mathrm{mL} / \mathrm{min}$. The ultraviolet absorbance was monitored at $280 \mathrm{~nm}$, and the identification of the peptides was confirmed by a coinjection with cold 4-F-T140. The retention time of cold 4-FT140 was $17.1 \mathrm{~min}$.

\section{Chinese Hamster Ovarian (CHO) and CHO-CXCR4 Cell Culture}

$\mathrm{CHO}$ cells and $\mathrm{CHO}$ cells that were stably transfected with CXCR4 (CHO-CXCR4) were a kind gift from Dr. David McDermott (National Institute of Allergy and Infectious Diseases, $\mathrm{NIH}$ ). The $\mathrm{CHO}$ cells were grown in $\mathrm{F}-12 \mathrm{~K}$ medium (American Type Culture Collection). All cell culture medium were supplemented with $10 \%$ fetal bovine serum, $1 \mathrm{mM}$ sodium pyruvate, 2 $\mathrm{mM}$ L-glutamine, and nonessential amino acids (Gibco). CXCR4 levels on CHO-CXCR4 were evaluated using a FlowCellect kit (Millipore) following the manufacturer's instructions, which indicated $6.8 \times 10^{5}$ receptors per cell. 


\section{CXCR4 Competition Cell Binding Assay}

$\mathrm{CHO}$ and $\mathrm{CHO}-\mathrm{CXCR} 4$ cells were trypsinized and resuspended in PBS containing $50 \mathrm{mM} N$-(2-hydroxyethyl)piperazine- $N^{\prime}$-(2ethanesulfonic acid), $1 \mathrm{mM} \mathrm{CaCl} 2,5 \mathrm{mM} \mathrm{MgCl}_{2}, 0.5 \%$ (w/v) bovine serum albumin, and $0.3 \mathrm{mM} \mathrm{NaN}_{3}$. Incubation was conducted in $200 \mu \mathrm{L}$ of a solution containing $10^{5}$ cells, $0.065 \mathrm{nM}^{125} \mathrm{I}-$ SDF-1 (Perkin-Elmer), and 0-1,000 nM of cold 4-F-T140 for $45 \mathrm{~min}$ on a shaker at room temperature. After incubation, cells were spun through $10 \%$ sucrose using a desktop Eppendorf centrifuge at 14,000 rpm. Cell-bound radioactivity was measured using a $\gamma$-counter (1480 Wizard 3; Perkin-Elmer). Binding results were expressed as percentage of total counts; inhibitory concentration of 50\% was calculated using Prism (GraphPad).

\section{Transwell Migration Assay}

The migration assay was done using Jurkat cells, which are an immortalized line of $\mathrm{T}$ lymphocytes that are able to migrate in response to SDF-1. Migration medium $(600 \mu \mathrm{L})$ (RPMI supplemented with $1 \%$ fetal bovine serum) containing $100 \mathrm{nM}$ SDF-1 (PeproTech) and different concentrations of cold 4-F-T140 (0-100 $\mathrm{nM}$ ) were placed into the lower chamber of a Costar 24-well Transwell (Corning). Jurkat cells $\left(10^{5}\right)$ in $100 \mu \mathrm{L}$ of migration medium were placed into the upper chamber (pore size, $5 \mu \mathrm{m}$ ), and cells were collected from the lower chamber after $3 \mathrm{~h}$ of migration at $37^{\circ} \mathrm{C}$ and counted by flow cytometry using counting beads. Control migrations were performed without the chemokine in the lower chamber.

\section{Tumor Xenograft Model}

Athymic nude mice were purchased from Taconic and housed under pathogen-free conditions. All animal studies were conducted in accordance with the principles and procedures outlined in the Guide for the Care and Use of Laboratory Animals (20) and under protocols approved by the NIH Clinical Center Animal Care and Use Committee. Mice were injected subcutaneously at 2 sites on the back or shoulder with $10^{6}$ CXCR4-positive or CXCR4negative $\mathrm{CHO}$ tumor cells per site. In some experiments, mice were inoculated with only CHO-CXCR4. The tumors were allowed to develop for 2 wk before imaging or biodistribution studies.

\section{Analysis of $4-{ }^{18} \mathrm{~F}-\mathrm{T} 140$ in Blood Fractions}

Mice were injected with $0.925 \mathrm{MBq}(25 \mu \mathrm{Ci})$ of $4-{ }^{18} \mathrm{~F}-\mathrm{T} 140$ (carrier-free). At $3 \mathrm{~h}$ after injection, blood was withdrawn from the hearts of euthanized mice using heparin-filled syringes and transferred into $15-\mathrm{mL}$ tubes. Cells were separated from plasma by centrifugation; the resulting pellet was washed 3 times with cold PBS, and the supernatant containing the serum was kept. Thereafter, red blood cells were lysed using $5 \mathrm{~mL}$ of ACK lysis buffer (BioWhittaker) solution for $1 \mathrm{~min}$, after which $10 \mathrm{~mL}$ of cold PBS were added. The remaining white blood cells (WBCs) were washed 3 more times with cold PBS, and the supernatant of the washes was kept as a red blood cell fraction. Radioactivity in each fraction was measured using a $\gamma$-counter. Results were expressed as a percentage of the total of the 3 fractions.

\section{Biodistribution}

About $0.925-1.85 \mathrm{MBq}(25-50 \mu \mathrm{Ci})$ of $4-{ }^{18} \mathrm{~F}-\mathrm{T} 140$ (carrierfree) in a volume of $100 \mu \mathrm{L}$ of PBS were injected through the tail veins of tumor-bearing mice. For the blocking experiment, 10, 20 , or $50 \mu \mathrm{g}$ of cold $4-\mathrm{F}-\mathrm{T} 140$ were coinjected with the labeled peptide. At 1, 2, or $3 \mathrm{~h}$ after injection, blood was drawn from the heart, under anesthesia, and the mice were then sacrificed. Spleen, liver, muscle, kidneys, intestine, bone, and tumors were removed. Bone marrow was flushed from within the bones, and the remaining organs were weighed. All organs were assayed for radioactivity using a $\gamma$-counter.

Blocking experiments with SDF-1 were done by injecting the mice with $15 \mu \mathrm{g}$ of the chemokine $20 \mathrm{~min}$ before injection of the tracer and then again together with the tracer (for a total of $30 \mu \mathrm{g}$ of chemokine per mouse). The results were calculated as percentage injected dose per gram of tissue $(\% \mathrm{ID} / \mathrm{g})$. Each group contained 5-6 mice.

\section{PET Studies}

Tumor-bearing mice were anesthetized using isoflurane $/ \mathrm{O}_{2}$ $(1.5 \%-2 \% \mathrm{v} / \mathrm{v})$ and injected with $4-{ }^{18} \mathrm{~F}-\mathrm{T} 140$ (carrier-free) and 10,20 , or $50 \mu \mathrm{g}$ of cold 4-F-T140 as described in the "Biodistribution" section. PET scans were performed using an Inveon DPET scanner (Siemens Medical Solutions). The scans were done 1, 2, and $3 \mathrm{~h}$ after radiotracer injection and recorded with a 100- to 700keV energy window. The images were reconstructed by a 2-dimensional ordered-subsets expectation maximum algorithm, and no correction was applied for attenuation or scatter. Images were analyzed using ASI Pro VM software.

\section{Statistical Analysis}

Results were expressed as mean and SD. Two-tailed paired and unpaired Student $t$ tests were used to test differences within groups and between groups, respectively. $P$ values less than 0.05 were considered statistically significant.

\section{RESULTS}

\section{Labeling of ${ }^{4-18} \mathrm{~F}-\mathrm{T} 140$}

${ }^{18} \mathrm{~F}-\mathrm{SFB}$ radiosynthesis was automated in 3 steps using a 2-reaction-vial module (Fig. 2). ${ }^{18} \mathrm{~F}$-fluoride displacement on pentamethylbenzyl 4-( $N, N, N$-trimethylammonium $)$ benzoate trifluoromethanesulfonate was performed in the first reaction vial. Hydrolysis of $4-{ }^{18} \mathrm{~F}$-fluorobenzoic acid pentamethylphenylmethyl ester to give ${ }^{18} \mathrm{~F}-\mathrm{FBA}$, followed by coupling of ${ }^{18} \mathrm{~F}$-FBA with $N, N^{\prime}$-disuccinimidyl carbonate and 4-(dimethylamino)pyridine, was conducted in the second reaction vial. The decay-corrected yields of ${ }^{18} \mathrm{~F}-\mathrm{SFB}$ obtained after C18 cartridge purification and evaporation of the solvent were $50 \%-60 \%$ based on starting ${ }^{18} \mathrm{~F}$ fluoride radioactivity. The total synthesis time was $90 \mathrm{~min}$. ${ }^{18} \mathrm{~F}-\mathrm{SFB}$ was achieved in high radiochemical purity $(>99 \%)$, as determined by radio-TLC $\left(\mathrm{R}_{\mathrm{f}}=0.9\right)$, for the coupling reaction with the peptide, without need for HPLC purifications.

${ }^{18}$ F-SFB conjugation to Dde-protected $\mathrm{T} 140$ peptide occurred on the $\alpha$-amino group of the $\mathrm{N}$ terminus (Fig. 2). Radio-TLC showed that the conjugation of ${ }^{18} \mathrm{~F}-\mathrm{SFB}$ onto the $\alpha$-amino group was not completely accomplished after $40 \mathrm{~min}$. Neither using a longer reaction time nor heating to a temperature of $40-50^{\circ} \mathrm{C}$ improved the conversion to the desired labeled peptide, and $35 \%-40 \%$ of ${ }^{18} \mathrm{~F}-\mathrm{SFB}$ remained unreactive. Adding more T140-protected peptide did, however, result in higher conversion, reaching a plateau of $40 \%$ conversion when using $1 \mathrm{mg}$ or more (Supplemental Fig. 1; supplemental materials are available online 


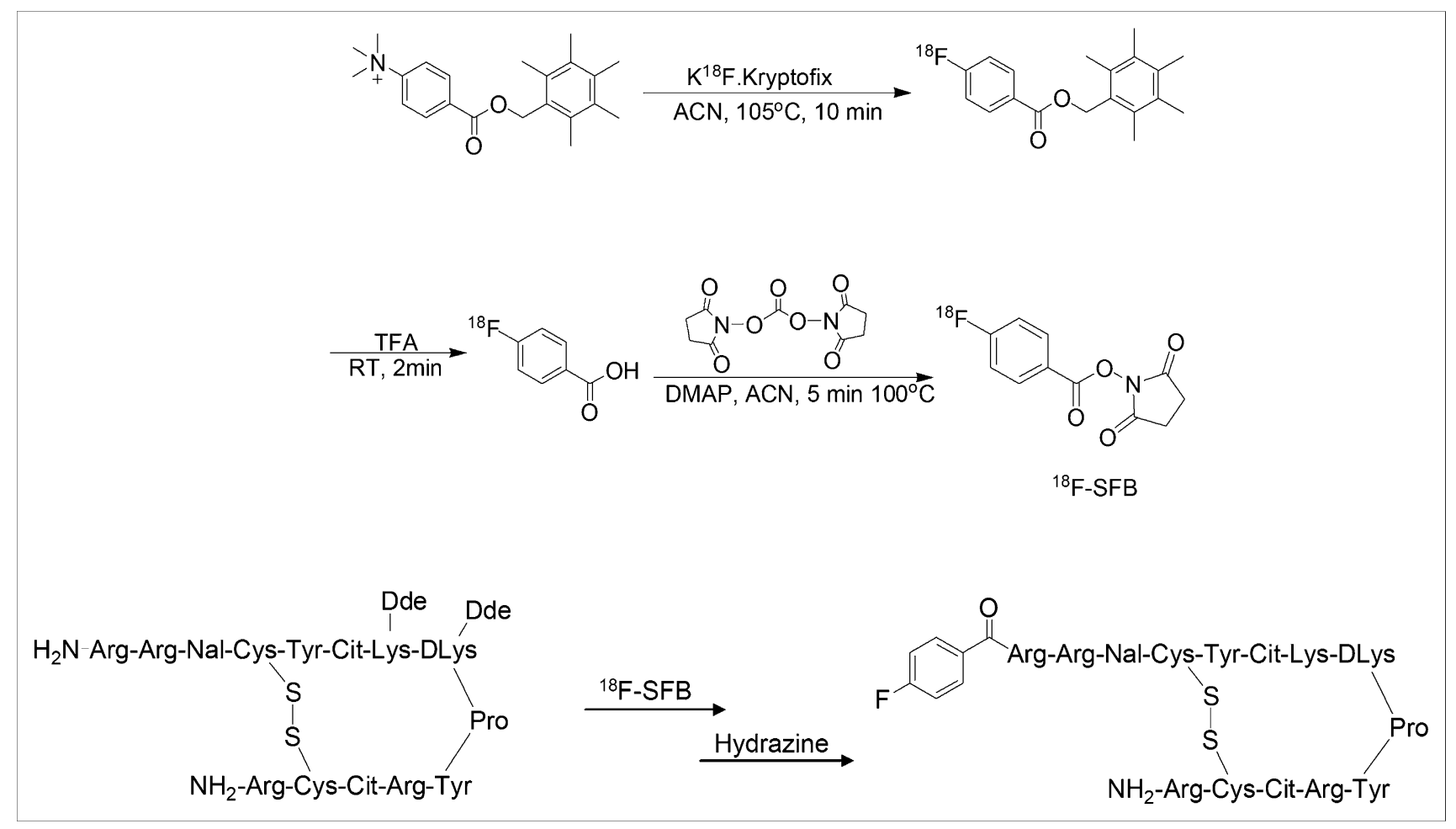

FIGURE 2. Radiosynthesis of $4-{ }^{18} \mathrm{~F}-\mathrm{T} 140 . \mathrm{ACN}=$ acetonitrile; DMAP $=4$-(dimethylamino)pyridine; $\mathrm{RT}=$ room temperature.

only at http://jnm.snmjournals.org). Attempts to improve the conversion by increasing the $\mathrm{pH}$ of the reaction caused precipitation of the T140-protected peptide, probably because of the lower pKa of the $\alpha$-amino group.

Dde was hydrolyzed by adding $2 \%$ hydrazine to the reaction vial. After $10 \mathrm{~min}$ of incubation at room temperature, the peptide hydrolysis was completed and purified on HPLC. Two major radioactive peaks were detected by HPLC. The unreacted ${ }^{18} \mathrm{~F}-\mathrm{SFB}$ was hydrolyzed to give ${ }^{4-}{ }^{18} \mathrm{~F}$-fluorobenzoic acid hydrazide (at a retention time of $7.1 \mathrm{~min}$ ) and $4-{ }^{18} \mathrm{~F}-\mathrm{T} 140$ (at a retention time of $23.6 \mathrm{~min}$ ). A minor peak of ${ }^{18} \mathrm{~F}-\mathrm{FBA}$ was also detected at a retention time of $16.5 \mathrm{~min}$. The radiochemical purity of the labeled peptide was greater than $99 \%$, according to analytic HPLC and radio-TLC, and specific activity was $7 \pm 2 \mathrm{GBq} / \mu \mathrm{mol}$ $(0.19 \pm 0.05 \mathrm{Ci} / \mu \mathrm{mol})$ at the end of synthesis. The overall decay-corrected yield of $4-{ }^{18} \mathrm{~F}-\mathrm{T} 140$ was $15 \% \pm 5 \%(n=$ 6 ), counted from the start of synthesis.

\section{Binding and Migration Inhibition Properties of 4-F-T140}

CHO cells transfected with human CXCR4 (Fig. 3A) expressed $6.8 \times 10^{5}$ CXCR4 molecules on their surfaces-a level that was slightly higher than the levels reported for tumor cells (21). The affinity of 4-F-T140 to CHO-CXCR4 cells was evaluated in a competitive binding assay with radiolabeled ${ }^{125}$ I-SDF-1 (Fig. 3B). The inhibitory concentration of 50\% of 4-F-T140 binding to CHO-CXCR4 cells was $2.5 \mathrm{nM}$, which was on the same order of magnitude as the functional inhibitory concentration of $50 \%(1 \mathrm{nM})$ required to inhibit Jurkat cell migration to SDF-1 (Fig. 3C). Our results were similar to the functional activity and binding reported previously by Tamamura et al. $(22,23)$.

\section{Biodistribution and PET}

Biodistribution of $4-{ }^{18} \mathrm{~F}-\mathrm{T} 140$ was analyzed, using PET scans in live animals and organ dissection with $\gamma$-counting, in female nude mice that had been inoculated subcutaneously with CHO-CXCR4 and CHO tumors. Data were obtained at 1,2, and $3 \mathrm{~h}$ after injection.

$4-{ }^{18} \mathrm{~F}-\mathrm{T} 140$ had a relatively high uptake over time in CXCR4-expressing organs. For example, accumulation in the spleen increased from $8 \pm 1 \% \mathrm{ID} / \mathrm{g}$ at $1 \mathrm{~h}$ to $12 \pm 2 \%$ $\mathrm{ID} / \mathrm{g}$ at $3 \mathrm{~h}$ and in the bone marrow from $0.78 \pm 0.22 \% \mathrm{ID} /$ $\mathrm{g}$ at $1 \mathrm{~h}$ to $2.6 \pm 0.65 \% \mathrm{ID} / \mathrm{g}$ at $3 \mathrm{~h}$ after injection (Fig. $4 \mathrm{~A}$ ). $4-{ }^{18} \mathrm{~F}-\mathrm{T} 140$ had a low accumulation in metabolic organs, such as the liver, intestine, and kidneys (Fig. 4A). $4-{ }^{18} \mathrm{~F}-$ T140 showed a higher uptake in CHO-CXCR4 tumors (2.3 $\pm 0.7 \% \mathrm{ID} / \mathrm{g})$ than in CXCR4-negative CHO tumors (1.7 \pm $0.92 \% \mathrm{ID} / \mathrm{g}$ ), but the difference was not statistically significant. Extremely high blood uptake and retention were observed $(14.7 \pm 2.6 \% \mathrm{ID} / \mathrm{g}$ at $3 \mathrm{~h}$ after injection) (Fig. $4 \mathrm{~A})$, contradicting the typical rapid clearance of smallmolecular-weight peptides (24).

Coinjection of $4-{ }^{18} \mathrm{~F}-\mathrm{T} 140$ and different amounts of cold 4-F-T140 $(10,20$, and $50 \mu \mathrm{g})$ into tumor-bearing mice significantly reduced the accumulation of $4-{ }^{18} \mathrm{~F}-\mathrm{T} 140$ in the blood, spleen, bone marrow, and wild-type $\mathrm{CHO}$ tumor, 

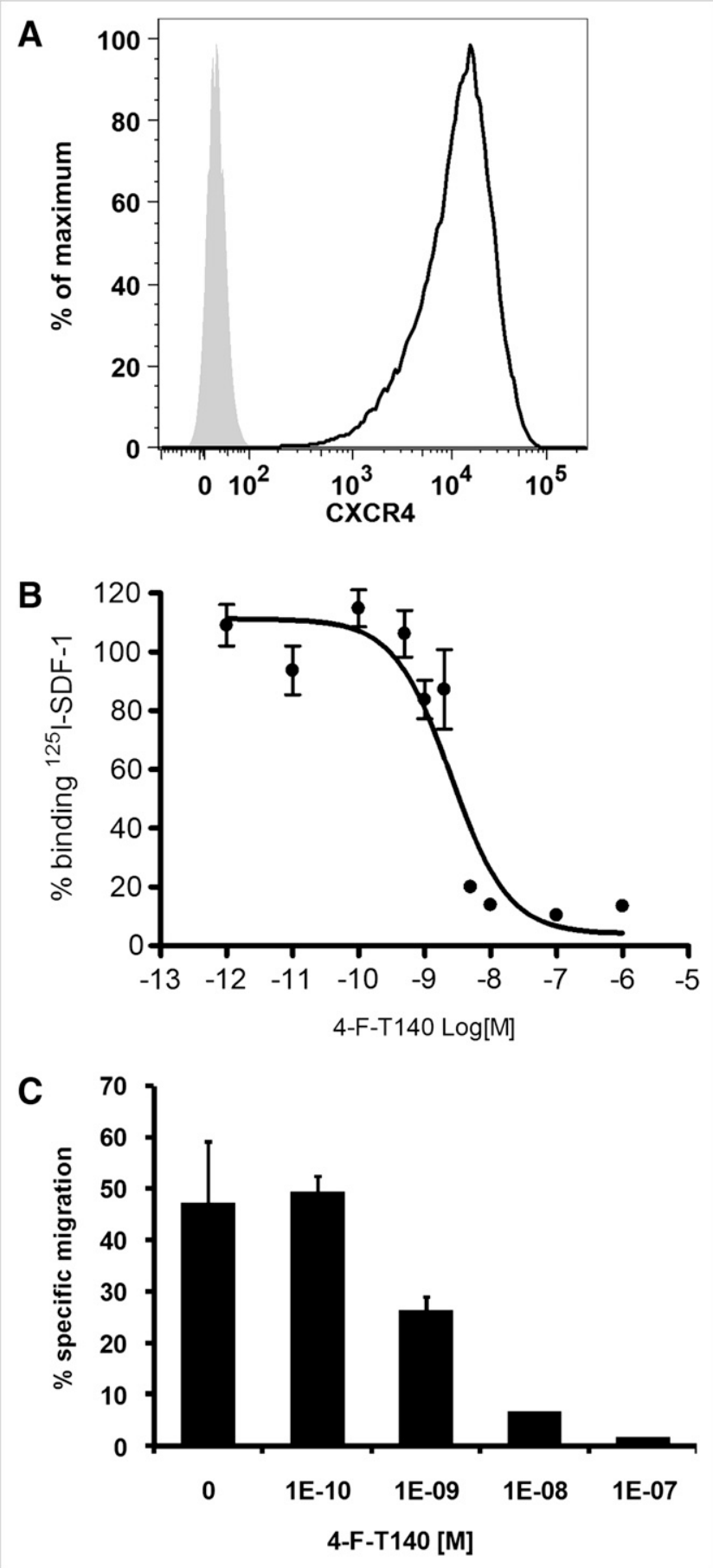

FIGURE 3. (A) CXCR4 expression by $\mathrm{CHO}-\mathrm{CXCR} 4$ cells, evaluated by flow cytometry. Gray histogram represents isotype control staining. Solid line represents anti-CXCR4 staining. (B) Competition binding assay of $4-\mathrm{F}-\mathrm{T} 140$ with ${ }^{125} \mathrm{I}-\mathrm{SDF}$ using $\mathrm{CHO}-\mathrm{CXCR} 4$ cell line. (C) Inhibition of SDF-1-induced migration of Jurkat cells by 4-F-T140.

whereas the accumulation in CHO-CXCR4 tumor was slightly increased (Fig. 4B). Chemokine binding to chemokine receptors induces internalization of the receptor; hence, some of the mice were injected with high amounts of SDF-1. Injection of SDF-1 insignificantly affected radio- labeled peptide levels in the blood and in CXCR4-positive tumors. However, injection of SDF-1 significantly reduced the accumulation of labeled peptide in CXCR4-expressing organs, such as the spleen and bone marrow (Fig. 4B).

The significant reduction in radioactivity in the blood after coinjection of labeled and cold peptide suggested that some of the apparent uptake in different organs was due to background signal from blood flow and not specific binding. To explore peptide accumulation in the blood, mice were injected with $0.925 \mathrm{MBq}(25 \mu \mathrm{Ci})$ of $4-{ }^{18} \mathrm{~F}-$ T140, blood was drawn at $3 \mathrm{~h}$ after injection, and radioactivity was measured in the plasma and cell fractions. Surprisingly, most of the radioactivity was found in the cell fractions, and the plasma had low accumulation of the radioactive peptide $(1.3 \%)$. To identify the cell type that binds $4-{ }^{18} \mathrm{~F}-\mathrm{T} 140$, we lysed the blood cells, measured the 2 remaining fractions, and found that most of the labeled peptide $(94.5 \%)$ was in the fraction containing the lysed red blood cells (RBCs), whereas the WBC fraction had a low accumulation of $4.1 \%$ (Fig. 4C). Similar to the biodistribution results, coinjection of the radiolabeled peptide with $50 \mu \mathrm{g}$ of cold peptide blocked the binding of $4-{ }^{18} \mathrm{~F}-$ T140 to RBCs, and low amounts of $4-{ }^{18} \mathrm{~F}-\mathrm{T} 140$ remained in the blood $(0.63 \pm 0.3 \% \mathrm{ID} / \mathrm{g})$. Moreover, the distribution of the labeled peptide within the blood compartments changed, with most of the radioactivity occurring in the plasma $\left(52.6 \%\right.$, Fig. 5C). The amount of $4-{ }^{18} \mathrm{~F}-\mathrm{T} 140$ in the WBC compartment also decreased $(2.86 \%)$ with an addition of cold mass (i.e., nonradioactive 4-F-140), probably because some WBCs express CXCR4 and the specific uptake was blocked.

Blocking the uptake in the RBCs by adding 3 different amounts of cold 4-F-T140 (10, 20, and $50 \mu \mathrm{g})$ significantly increased the tumor-to-blood and tumor-to-muscle ratios in comparison to the result achieved with no cold mass at all (Table 1). The lowest amount of cold peptide, $10 \mu \mathrm{g}$, gave the highest tumor-to-blood and tumor-to-muscle ratios $(27.05 \pm 8.7$ and $21.6 \pm 7.14$, respectively), and addition of the highest amount, $50 \mu \mathrm{g}$, gave the lowest tumor-toblood and tumor-to-muscle ratios $(6.15 \pm 2.65$ and $10.41 \pm$ 5.3, respectively). Further analysis of the results showed that addition of 10 or $20 \mu \mathrm{g}$ of cold 4-F-T140 had more effect on the background, reducing the $\% \mathrm{ID} / \mathrm{g}$ in the blood (from $14.3 \% \pm 2.63 \%$ to $0.12 \% \pm 0.04 \%$ and $0.19 \% \pm$ $0.07 \%$, respectively), whereas $50 \mu \mathrm{g}$ resulted in a higher $\% \mathrm{ID} / \mathrm{g}$ in the blood $(0.63 \% \pm 0.36 \%)$ (Supplemental Table 1).

Biodistribution results were validated by noninvasive PET using mice bearing $\mathrm{CHO}$ and CHO-CXCR4 tumors that were injected with $4-{ }^{18} \mathrm{~F}-\mathrm{T} 140$ alone (Fig. 5A left), which clearly showed both tumors, or with $50 \mu \mathrm{g}$ of cold peptide (Fig. 5A right), which detected CXCR4-positive, but not CXCR4-negative, tumors.

PET after coinjection with various amounts of cold peptide into mice bearing only CHO-CXCR4 tumor showed the highest uptake in the CHO-CXCR4 tumors when $10 \mu \mathrm{g}$ 


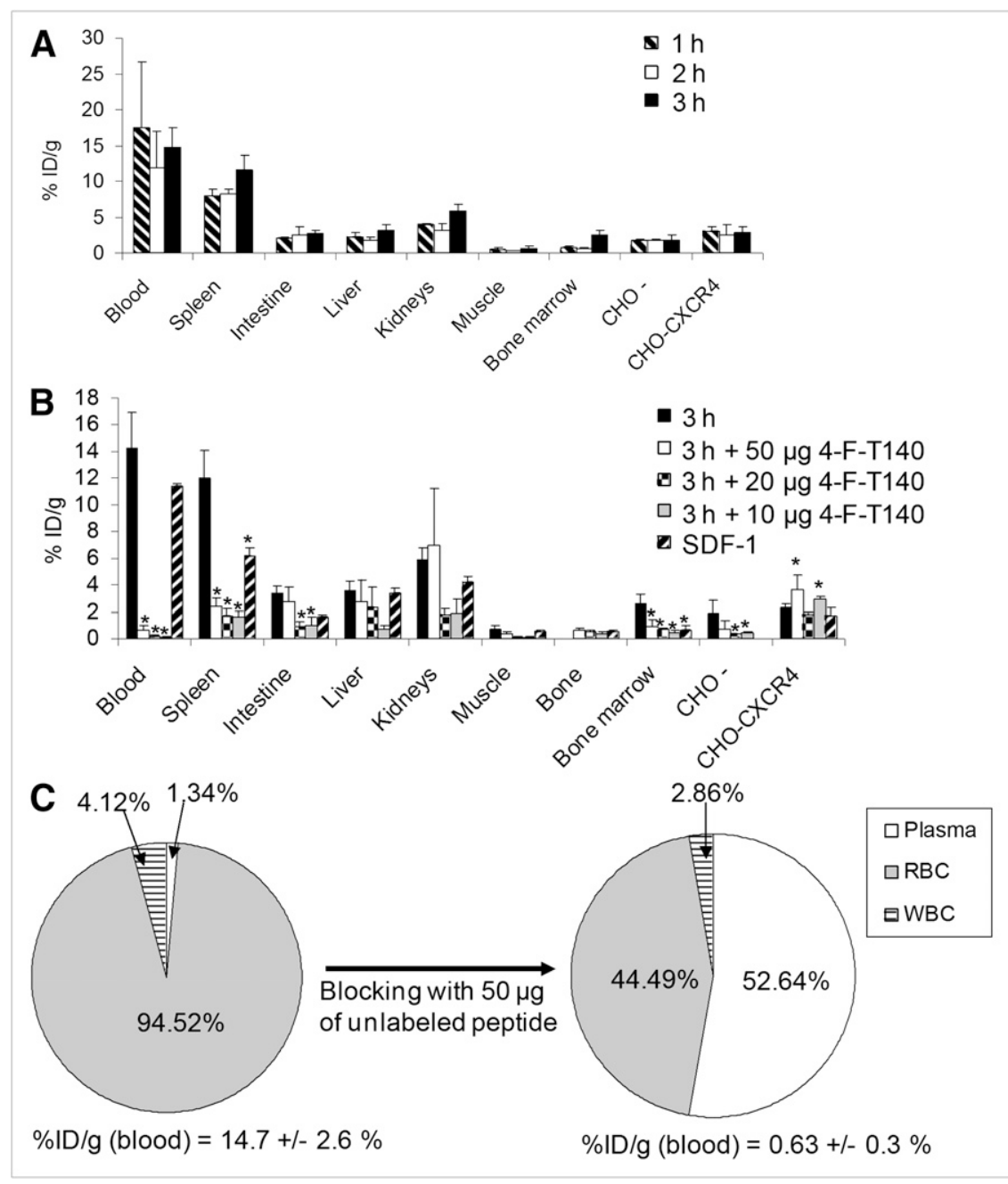

FIGURE 4. (A) Biodistribution of $4-{ }^{18} \mathrm{~F}-\mathrm{T} 140$ in female athymic nude mice bearing $\mathrm{CHO}$ and $\mathrm{CHO}-\mathrm{CXCR} 4$ tumors at 1,2 , and $3 \mathrm{~h}$ after injection of labeled peptide. Results shown are averages of 6 mice \pm SD. (B) Biodistribution of $4-{ }^{18} \mathrm{~F}-\mathrm{T} 140$ in female athymic nude mice bearing $\mathrm{CHO}$ and $\mathrm{CHO}-\mathrm{CXCR} 4$ tumors at $3 \mathrm{~h}$ after injection of labeled peptide in presence of different amounts of cold peptide $(10,20$, and $50 \mu \mathrm{g})$. Results shown are averages of 5-6 mice \pm SD. ${ }^{*} P<0.01$ vs. 4-18F-T140 alone. (C) 4-18F-T140 distribution in blood withdrawn from mice at $3 \mathrm{~h}$ after injection. Left pie shows blood distribution of $4-{ }^{18} \mathrm{~F}-\mathrm{T} 140$ alone. Right pie shows blood distribution of $4-{ }^{18} \mathrm{~F}-\mathrm{T} 140$ when coinjected with $50 \mu \mathrm{g}$ of cold $4-\mathrm{F}-\mathrm{T} 140$. Total \%ID/g in blood is indicated below each pie. Results shown are averages of 3 mice per group. were added (3.3\% \%D/g). They also had a high tumor-tobackground ratio, corroborating the direct tissue sampling biodistribution studies (Fig. 5B).

\section{DISCUSSION}

CXCR4 antagonists, both peptide-based (e.g., T140) and small molecules (e.g., AMD3100), have been developed as potential therapeutics for anti-HIV activity (25). T140 is a 14-residue peptide having a disulfide bond and is considered to be a potent CXCR4 peptide antagonist for anti-HIV activity (22). However, it has shown a lack of serum stability due to cleavage of the C-terminal arginine (22). Therefore, C-terminally amidated T140 analogs have been developed to overcome serum instability, leading to the synthesis of several T140 derivatives (22). 4-F-TN14003 (4-F-T140) is a modified T140 peptide, consisting of 14 amino acids, 1 disulfide bridge between $\mathrm{Cys}^{4}$ and $\mathrm{Cys}^{13}$, an amidated C terminus, and a 4-fluorobenzoyl group at the $\mathrm{N}$ terminus (Fig. 1) (23,26). 4-F-T140 is a highly selective CXCR4 antagonist and has been shown to be stable in rat liver homogenate (26). Importantly, 4-F-T140 shows increased in vivo mobilization of stem cells from the bone marrow when compared with the approved drug AMD3100/ plerixafor (27).

In our studies, 4-F-T140 showed a high affinity to CXCR4 and high inhibition potency for migration of CXCR4-positive Jurkat cells toward high concentration of SDF-1 (Figs. 3B and 3C). Previous attempts to image CXCR4 levels in the tumor using SPECT have been reported. For example, labeling of a T140 derivative, AcTZ14011, with ${ }^{111}$ In resulted in accumulation in the spleen and high uptake in the kidneys and liver and displayed low accumulation in tumors (28). ${ }^{125}$ I-labeled CXCR4-specific antibody, 12G5, had relatively higher accumulation in CXCR4-positive tumors than did ${ }^{111}$ In-AC-TZ14011, although only 2 -fold higher than that observed using an isotype-identical control antibody (29). Scanning using the labeled antibody also required a long delay after injection, and detection was limited to large tumors $(>200$ $\mathrm{mm}^{3}$ ). Together, these factors may limit the use of $12 \mathrm{G} 5$ as a clinical imaging agent.

Imaging of CXCR 4 using ${ }^{18} \mathrm{~F}$ has many advantages due to its ideal nuclear properties for PET: $97 \%$ of the isotope decay is by positron emission (30-32), and it has fairly low- 

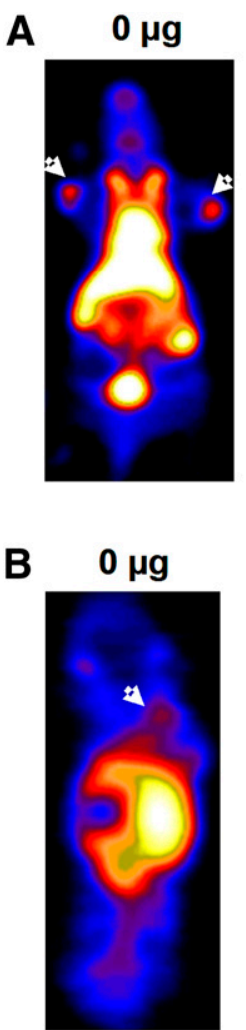

FIGURE 5. (A) Representative coronal PET images of an athymic nude mouse bearing $\mathrm{CHO}-\mathrm{CXCR} 4$ (left shoulder) and $\mathrm{CHO}$ (right shoulder) at $2 \mathrm{~h}$ after injection with $50 \mu \mathrm{Ci}$ of $4-{ }^{18} \mathrm{~F}-\mathrm{T} 140$ (left) or coinjection with $50 \mu \mathrm{g}$ of cold peptide (right). Arrows indicate tumors. (B) Representative PET images of athymic nude mouse bearing only $\mathrm{CHO}-\mathrm{CXCR} 4$ tumors on its back, at $2 \mathrm{~h}$ after injection of $25 \mu \mathrm{Ci}$ of $4-{ }^{18} \mathrm{~F}-\mathrm{T} 140$ alone, or coinjection with 10,20 , and $50 \mu \mathrm{g}$ of $4-\mathrm{F}-\mathrm{T} 140$. Upper row is dorsal slices, with arrows indicating CXCR4-CHO tumor. Lower row is ventral slices.

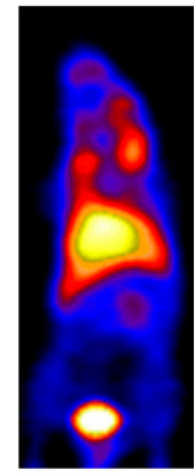

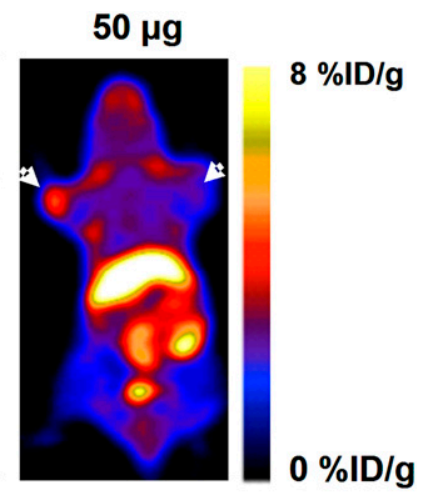
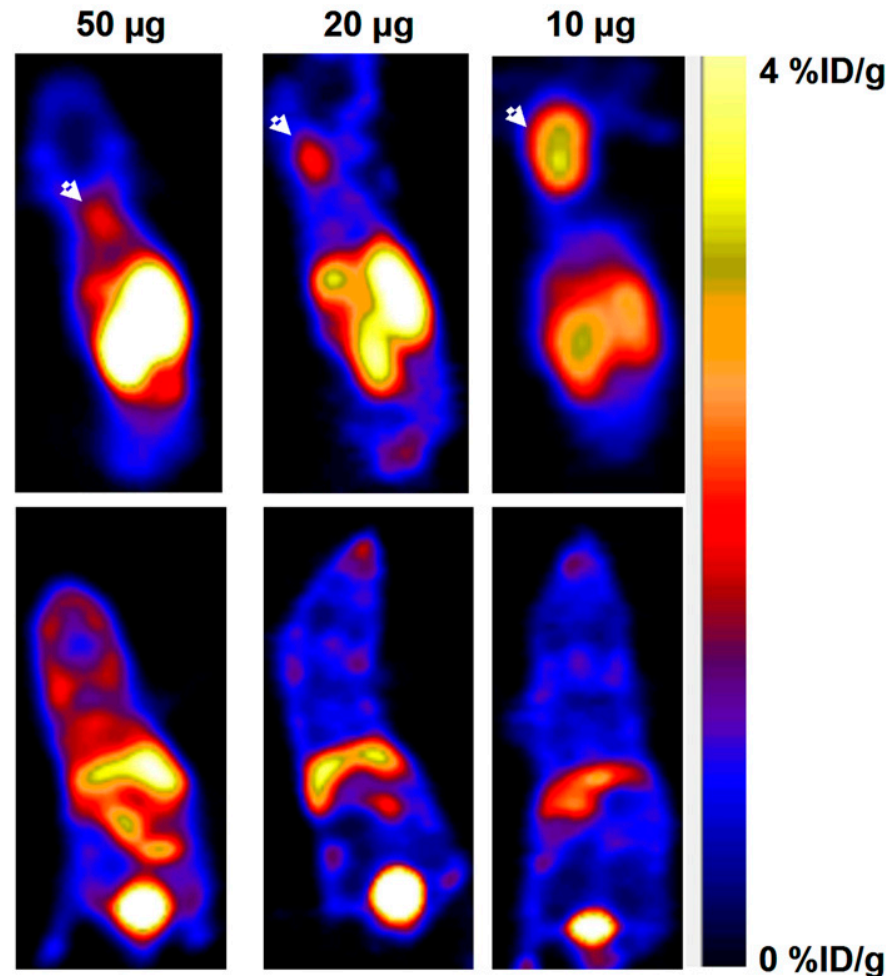

$0 \% \mathrm{ID} / \mathrm{g}$ energy positron emission and, therefore, a short linear range in live tissue. ${ }^{18} \mathrm{~F}$ has an optimal half-life of $109.8 \mathrm{~min}$, which is considered acceptable for chemical syntheses. 4-F-T140 already contains an aromatic fluoride on the benzoyl group (Fig. 1). To prevent its chemical structure from changing, T140-protected peptide was conjugated to ${ }^{18} \mathrm{~F}$ SFB on the $\alpha$-amino, with a reasonable yield (Fig. 2).

Initial evaluation of ${ }^{4-}{ }^{18} \mathrm{~F}-\mathrm{T} 140$ in tumor-bearing mice showed high and persistent retention of the labeled peptide in the blood, resulting in visualization of both CXCR4-negative and CXCR-4-positive tumors, probably because of an enhanced but similar blood supply to the tumors (Fig. 5A). Further investigation revealed that RBCs bind ${ }^{4}-{ }^{18} \mathrm{~F}-\mathrm{T} 140$ (Fig. 4C), possibly making most of the peptide unavailable to bind CXCR4 elsewhere. RBCs were not previously reported to express CXCR4, and accordingly, the coinjection of high amounts of SDF-1 with ${ }^{4-}{ }^{18} \mathrm{~F}-\mathrm{T} 140 \mathrm{did}$ not block the binding of the peptide to these cells (Fig. 4B).
However, SDF-1 injection did have a blocking effect on ${ }^{4-}{ }^{18} \mathrm{~F}-\mathrm{T} 140$ accumulation in other CXCR4-expressing organs, such as the spleen and bone marrow. Although we did not discover to which receptor on RBCs the peptide binds, these cells were previously reported to express receptors such as Duffy antigen that are able to bind to various chemokines (33) and might bind $4-{ }^{18} \mathrm{~F}-\mathrm{T} 140$ as well. Further studies to explore the binding of this peptide to RBCs might lead to ways to reduce the non-CXCR4 binding and improve the efficiency of the 4-F-T140 as an anti-CXCR4 therapy.

We suggest that once ${ }^{4-18} \mathrm{~F}-\mathrm{T} 140$ is injected, it first encounters RBCs, binds to them, and thereafter is not available for binding to CXCR4-expressing tumor cells. This can be overcome by coinjection of $4-{ }^{18} \mathrm{~F}-\mathrm{T} 140$ with an appropriate amount of cold peptide. The binding of nonradioactive $4-\mathrm{F}-140$ to $\mathrm{RBCs}$ allows $4-{ }^{18} \mathrm{~F}-\mathrm{T} 140$ to interact with CXCR4-expressing tumor cells but not with CXCR4negative tumor cells, which enables visualization of the 
TABLE 1

CHO-CXCR4 Tumor-to-Muscle and Tumor-

to-Blood Ratio at 3 Hours After Injection of 4-18F-T140 ( $n=5$ or 6 Mice per Group)

\begin{tabular}{|c|c|c|}
\hline $4-{ }^{18} \mathrm{~F}-\mathrm{T} 140(\mu \mathrm{g})$ & $\begin{array}{l}\text { Tumor-to-muscle } \\
\text { ratio }\end{array}$ & $\begin{array}{l}\text { Tumor-to-blood } \\
\text { ratio }\end{array}$ \\
\hline Alone & $2.94 \pm 0.16$ & $0.19 \pm 0.04$ \\
\hline+10 & $21.6 \pm 7.14^{*, \dagger}$ & $27.05 \pm 8.7^{\star, \dagger}$ \\
\hline+20 & $17.34 \pm 6.12^{*}$ & $9.7 \pm 3.26^{*}$ \\
\hline+50 & $10.41 \pm 5.3^{*}$ & $6.15 \pm 2.65^{\star}$ \\
\hline \multicolumn{3}{|c|}{$\begin{array}{l}{ }^{*} P<0.01 \text { vs. injection of } 4-{ }^{18} \mathrm{~F}-\mathrm{T} 140 \text { alone. } \\
{ }^{\dagger} P<0.01 \text { for injection of } 4-{ }^{-18} \mathrm{~F}-\mathrm{T} 140+10 \mu \mathrm{g} \text { of } 4-\mathrm{F}-\mathrm{T} 140 \text { vs. } \\
{ }^{18} \mathrm{~F}-\mathrm{T} 140+50 \mu \mathrm{g} \text { of } 4-\mathrm{F}-\mathrm{T} 140 .\end{array}$} \\
\hline
\end{tabular}

CXCR4-positive tumor with higher signal-to-noise ratio (Fig. 5B). Accordingly, CXCR4-positive tumor-to-blood ratio and tumor-to-muscle ratio are significantly increased (Table 1) from $0.19 \pm 0.04$ (tumor-to-blood) and $2.94 \pm$ 0.16 (tumor-to-muscle) to $27.05 \pm 8.7$ and $21.6 \pm 7.14$, respectively, with an addition of $10 \mu \mathrm{g}$ of 4-F-T140. In addition, we observed some dose response, when injecting increasing amounts of cold peptide, on tumor-to-blood and tumor-to-muscle ratios (Table 1; Fig. 5B). Moreover, using $50 \mu \mathrm{g}$ of cold $4-\mathrm{F}-\mathrm{T} 140$ resulted in higher $\% \mathrm{ID} / \mathrm{g}$ in the blood and higher background than when 10 or $20 \mu \mathrm{g}$ were injected (Supplemental Table 1). This effect suggests that blocking $4-{ }^{18} \mathrm{~F}-\mathrm{T} 140$ binding to RBCs with $10 \mu \mathrm{g}$ was sufficient in our mouse model and that increasing the amount of cold peptide begins to block specific binding of $4-{ }^{18} \mathrm{~F}-\mathrm{T} 140$ to CXCR4, resulting in higher amounts of $4-{ }^{18} \mathrm{~F}-\mathrm{T} 140$ in the blood.

Injection of $4-{ }^{18} \mathrm{~F}-\mathrm{T} 140$ alone resulted in similar uptake in both CXCR4-positive and -negative tumors. These results suggested that the blood flow in both tumors was similar. However, when $4-{ }^{18}$ F-T140 was injected with cold peptide, the uptake in CXCR4-negative tumor decreased, whereas in CXCR4-positive tumors uptake was elevated. These results imply that $4-{ }^{18} \mathrm{~F}-\mathrm{T} 140$ binding in the positive tumor is specific to CXCR4 and not simply the result of tumor blood flow.

\section{CONCLUSION}

4- ${ }^{18} \mathrm{~F}-\mathrm{T} 140$ can be used to determine tumor CXCR4 expression. Although $4-{ }^{18} \mathrm{~F}-\mathrm{T} 140$ binds to RBCs, this binding can be blocked by coinjection of the tracer with cold 4-F-T140 peptide, resulting in elevated accumulation in CXCR4-positive tumor, but not CXCR4-negative tumor, and high tumor-to-background ratios. Visualizing and quantifying CXCR4 expression by cancers could lead to more effective interventions tailored to the individual patient.

\section{ACKNOWLEDGMENTS}

We thank Dr. Amnon Peled from Hadassah-Hebrew University Medical Center, Jerusalem, Israel, for fruitful discussions. We also thank Dr. Henry S. Eden for proof- reading this manuscript. This research was supported by the Intramural Research Program (IRP) of the National Institute of Biomedical Imaging and Bioengineering (NIBIB) and the National Institute of Allergy and Infectious Diseases (NIAID) of the National Institutes of Health (NIH).

\section{REFERENCES}

1. Klein RS, Rubin JB. Immune and nervous system CXCL12 and CXCR4: parallel roles in patterning and plasticity. Trends Immunol. 2004;25:306-314.

2. Horuk R. Chemokine receptors. Cytokine Growth Factor Rev. 2001;12:313335.

3. Phillips RJ, Burdick MD, Lutz M, Belperio JA, Keane MP, Strieter RM. The stromal derived factor-1/CXCL12-CXC chemokine receptor 4 biological axis in non-small cell lung cancer metastases. Am J Respir Crit Care Med. 2003;167: 1676-1686.

4. Balkwill F. The significance of cancer cell expression of the chemokine receptor CXCR4. Semin Cancer Biol. 2004;14:171-179.

5. Tanaka T, Bai Z, Srinoulprasert Y, Yang BG, Hayasaka H, Miyasaka M. Chemokines in tumor progression and metastasis. Cancer Sci. 2005;96:317-322.

6. Muller A, Homey B, Soto H, et al. Involvement of chemokine receptors in breast cancer metastasis. Nature. 2001;410:50-56.

7. Taichman RS, Cooper C, Keller ET, Pienta KJ, Taichman NS, McCauley LK. Use of the stromal cell-derived factor-1/CXCR4 pathway in prostate cancer metastasis to bone. Cancer Res. 2002;62:1832-1837.

8. Rubin JB, Kung AL, Klein RS, et al. A small-molecule antagonist of CXCR4 inhibits intracranial growth of primary brain tumors. Proc Natl Acad Sci USA. 2003;100:13513-13518.

9. Redjal N, Chan JA, Segal RA, Kung AL. CXCR4 inhibition synergizes with cytotoxic chemotherapy in gliomas. Clin Cancer Res. 2006;12:6765-6771.

10. Lee HJ, Kim SW, Kim HY, et al. Chemokine receptor CXCR4 expression, function, and clinical implications in gastric cancer. Int J Oncol. 2009;34:473480.

11. Oda Y, Tateishi N, Matono $\mathrm{H}$, et al. Chemokine receptor CXCR4 expression is correlated with VEGF expression and poor survival in soft-tissue sarcoma. Int J Cancer. 2009;124:1852-1859.

12. Azab AK, Runnels JM, Pitsillides C, et al. CXCR4 inhibitor AMD3100 disrupts the interaction of multiple myeloma cells with the bone marrow microenvironment and enhances their sensitivity to therapy. Blood. 2009;113:4341-4351.

13. Kurtova AV, Tamayo AT, Ford RJ, Burger JA. Mantle cell lymphoma cells express high levels of CXCR4, CXCR5, and VLA-4 (CD49d): importance for interactions with the stromal microenvironment and specific targeting. Blood. 2009;113:4604-4613.

14. Zeng Z, Samudio IJ, Munsell M, et al. Inhibition of CXCR4 with the novel RCP168 peptide overcomes stroma-mediated chemoresistance in chronic and acute leukemias. Mol Cancer Ther. 2006;5:3113-3121.

15. Li JK, Yu L, Shen Y, Zhou LS, Wang YC, Zhang JH. Inhibition of CXCR4 activity with AMD3100 decreases invasion of human colorectal cancer cells in vitro. World J Gastroenterol. 2008;14:2308-2313.

16. Yoon Y, Liang Z, Zhang X, et al. CXC chemokine receptor-4 antagonist blocks both growth of primary tumor and metastasis of head and neck cancer in xenograft mouse models. Cancer Res. 2007;67:7518-7524.

17. Jacobson O, Weiss ID, Szajek L, Farber JM, Kiesewetter DO. ${ }^{64} \mathrm{Cu}-\mathrm{AMD} 3100$ : a novel imaging agent for targeting chemokine receptor CXCR4. Bioorg Med Chem. 2009; 17:1486-1493.

18. Nimmagadda S, Pullambhatla M, Stone K, Green G, Bhujwalla ZM, Pomper MG. Molecular imaging of CXCR4 receptor expression in human cancer xenografts with $\left[{ }^{64} \mathrm{Cu}\right] \mathrm{AMD} 3100$ positron emission tomography. Cancer Res. 2010;70:3935-3944.

19. Lang L, Jagoda E, Schmall B, et al. Development of fluorine-18-labeled 5-HT1A antagonists. J Med Chem. 1999;42:1576-1586.

20. Guide for the Care and Use of Laboratory Animals. Washington, DC: National Academy Press; 1996.

21. Lee B, Sharron M, Montaner LJ, Weissman D, Doms RW. Quantification of CD4, CCR5, and CXCR4 levels on lymphocyte subsets, dendritic cells, and differentially conditioned monocyte-derived macrophages. Proc Natl Acad Sci USA. 1999;96:5215-5220.

22. Tamamura H, Omagari A, Hiramatsu K, et al. Development of specific CXCR4 inhibitors possessing high selectivity indexes as well as complete stability in serum based on an anti-HIV peptide T140. Bioorg Med Chem Lett. 2001;11: 1897-1902. 
23. Tamamura H, Hori A, Kanzaki N, et al. T140 analogs as CXCR4 antagonists identified as anti-metastatic agents in the treatment of breast cancer. FEBS Lett. 2003;550:79-83.

24. Lee S, Xie J, Chen X. Peptides and peptide hormones for molecular imaging and disease diagnosis. Chem Rev. 2010;110:3087-3111.

25. Burger JA, Peled A. CXCR4 antagonists: targeting the microenvironment in leukemia and other cancers. Leukemia. 2009;23:43-52.

26. Tamamura H, Hiramatsu K, Mizumoto M, et al. Enhancement of the T140-based pharmacophores leads to the development of more potent and bio-stable CXCR4 antagonists. Org Biomol Chem. 2003;1:3663-3669.

27. Abraham M, Beider K, Wald H, et al. The CXCR4 antagonist 4F-benzoylTN14003 stimulates the recovery of the bone marrow after transplantation. Leukemia. 2009;23:1378-1388.
28. Hanaoka H, Mukai T, Tamamura H, et al. Development of a ${ }^{111} \mathrm{In}$-labeled peptide derivative targeting a chemokine receptor, CXCR4, for imaging tumors. Nucl Med Biol. 2006;33:489-494.

29. Nimmagadda S, Pullambhatla M, Pomper MG. Immunoimaging of CXCR4 expression in brain tumor xenografts using SPECT/CT. J Nucl Med. 2009;50:1124-1130.

30. Nickles RJ, Gatley SJ, Votaw JR, Kornguth ML. Production of reactive fluorine18. Int J Rad Appl Instrum [A]. 1986;37:649-661.

31. McQuade P, Rowland DJ, Lewis JS, Welch MJ. Positron-emitting isotopes produced on biomedical cyclotrons. Curr Med Chem. 2005;12:807-818.

32. Jacobson $\mathrm{O}$, Chen X. PET designated flouride- 18 production and chemistry. Curr Top Med Chem. 2010;10:1048-1059.

33. Rot A. Contribution of Duffy antigen to chemokine function. Cytokine Growth Factor Rev. 2005;16:687-694.

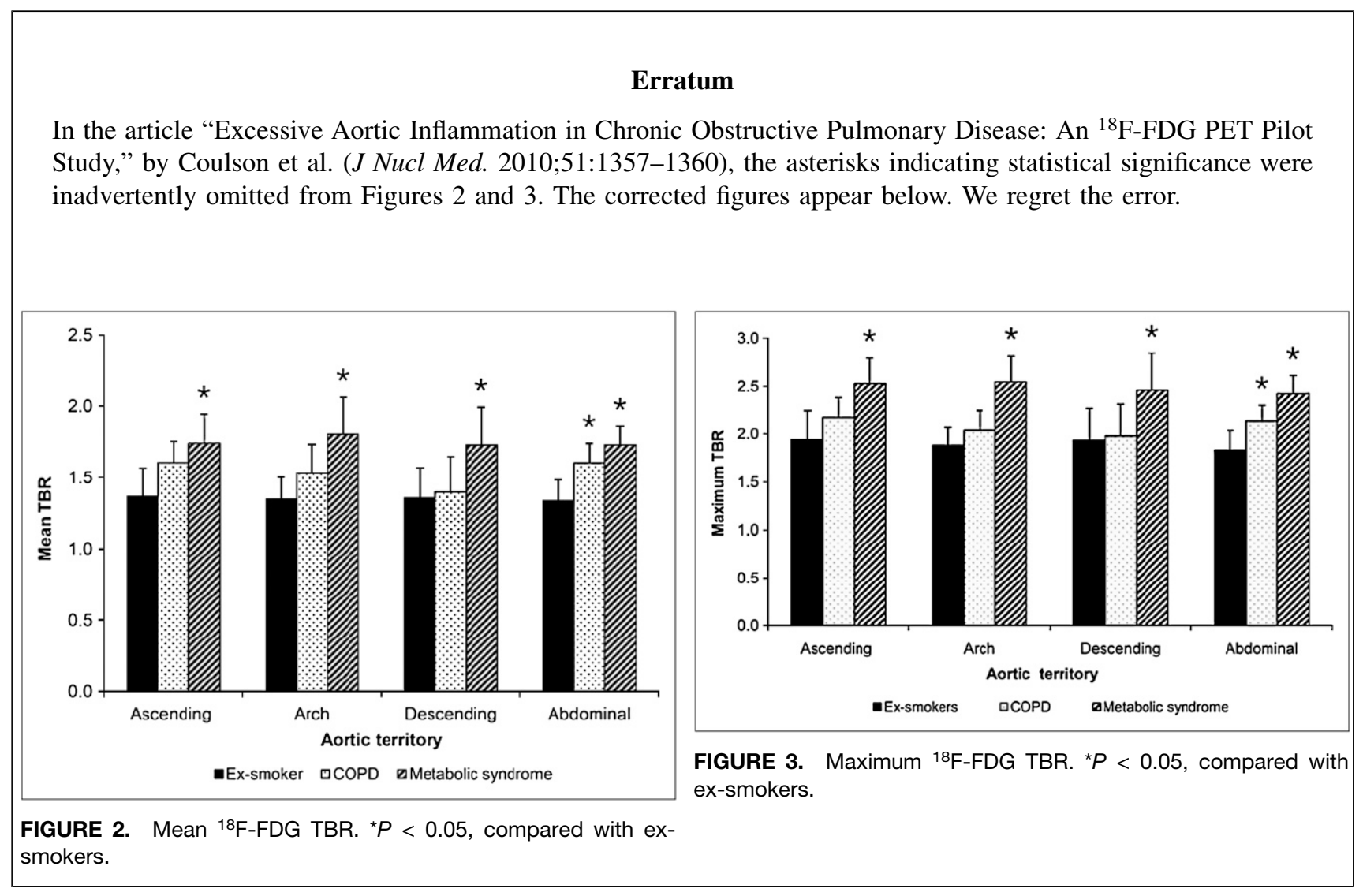

